\title{
Alkaloid profiling and antimicrobial activities of Papaver glaucum and P. decaisnei
}

Hawraz Jawdat Jafaar ${ }^{1}$, Ovgu Isbilen $^{1,2^{*}}$, Ender Volkan ${ }^{1,2}$ and Gunay Sariyar ${ }^{1}$

\begin{abstract}
Objective: Papaver decaisnei Hochst. \& Steud. Ex Elkan and Papaver glaucum Boiss. \& Hausskn. growing wild in Northern Iraq have been historically used for medicinal purposes. In this study, both species were evaluated for their alkaloid content and antimicrobial activities.

Results: Alkaloids were extracted and isolated by preparative thin-layer chromatography (TLC). Identification was carried out by comparing spectral data (UV and ${ }^{~} \mathrm{H}-\mathrm{NMR}$ ) and TLC Rf values with those of authentic samples. Two alkaloids, proapaorphine-type mecambrine and aporphine-type roemerine were isolated from P. decaisnei. Two benzylisoquinoline type alkaloids papaverine (major alkaloid) and palaudine as well as aporphine-type $\mathrm{N}$-methylasimilobine have been obtained in P. glaucum. Both P. glaucum and P. decaisnei extracts revealed strong antimicrobial activity on Pseudomonas aeruginosa ATCC 27853 and Enterococcus faecalis ATCC 29212. Collectively these results indicate that $P$. glaucum and $P$. decaisnei are promising sources of alkaloids that could further be investigated for medicinal purposes.
\end{abstract}

Keywords: Papaver decaisnei Hochst. \& Steud. Ex Elkan, Papaver glaucum Boiss. \& Hausskn., Alkaloids, Antimicrobial activity, ${ }^{1} \mathrm{H}-\mathrm{NMR}$ spectra

\section{Introduction}

Papaver somniferum is one of the oldest cultivated medicinal plants and still keeps its importance for the production of its main alkaloids codeine and morphine $[1,2]$. Thebaine, another major alkaloid in P. somniferum, is utilized as starting material for semisynthetic opioids oxycodone and buprenorphine [2]. Studies on the alkaloid content of different wild Papaver species have revealed many chemotypes, some of which contain thebaine as a major alkaloid along with other medicinally important alkaloids [3]. Alkaloids obtained from Papaver species show biological effects including persuasive narcotic, analgesic, anti-inflammatory, anti-hypertensive, antioxidant, antidepressant, anticancer, antimicrobial,

\footnotetext{
*Correspondence: oisbilen@ciu.edu.tr

1 Faculty of Pharmacy, Cyprus International University, via Mersin 10,

99258 Nicosia, Northern Cyprus, Turkey

Full list of author information is available at the end of the article
}

antidiarrheal activities as well as cholesterol and glucoselowering properties $[4,5]$.

There are 15 species of genus Papaver growing wild in Iraq grouped under 5 sections namely Papaver L., Carinatae Fedde, Rhoeadium, Argemonidium and Meconidium Bernh [6]. Section Papaver includes three species $P$. somniferum, $P$. decaisnei and P. glaucum [6]. To our knowledge, there is only one report on the alkaloid content of Papaver species from Iraq [3]. Aporphine (liriodenine, roemerine, dehydroroemerine, roemerine $\mathrm{N}$-oxides), rhoeadine (rhoeadine, rhoeagenine, glaucamine) and protopine-type (protopine) alkaloids have been shown together with some unidentified alkaloids of aporphine and 1-benzylisoquinoline nature in different samples of Iraqi herbarium materials [3].

The biologically active and medicinally significant nature of plants from genus Papaver have led us to investigate the alkaloids of understudied Papaver species, $P$. glaucum and $P$. decaisnei growing in northern Iraq along 
with elucidating their medicinal potential via studying their antimicrobial activities in-vitro.

\section{Main text \\ Methods \\ Plant material collection}

Samples of $P$. decaisnei and P. glaucum were collected from Northern Iraq at the flowering stage from Hawraman-Tawela and Rowanduz-Gorge region, Voucher specimens have been identified by Prof. Dr. Neriman Özhatay Chair of Pharmaceutical Botany, Eastern Mediterranean University and Prof. Dr. Mehmet Koyuncu Chair of Pharmaceutical Botany, Cyprus International University and deposited in Cyprus International University Public Herbarium (P. glaucum herbarium number: CIUH-126; $P$. decaisnei herbarium number: $\mathrm{CIUH}-127)$.

\section{Alkaloid extraction and isolation}

The dried $P$. decaisnei and P. glaucum aerial parts were each percolated with methanol at room temperature and evaporated to obtain syrup-like residue under vacuum. The residue was dissolved in $5 \%$ hydrochloric acid $(\mathrm{HCl})$ and extracted with light petroleum. The acidic fraction was made alkaline with $25 \%$ ammonia $\left(\mathrm{NH}_{3}\right)$ (Sigma Aldrich, Germany) to $\mathrm{pH}$ 7-8 and extracted successively with chloroform (Sigma Aldrich, Germany). Chloroform extracts were combined and dried over anhydrous sodium sulphate $\left(\mathrm{Na}_{2} \mathrm{SO}_{4}\right)$, filtered and concentrated at low pressure to yield total tertiary alkaloid extracts of $P$. decaisnei and P. glaucum [7].

\section{Preparative thin layer chromatography (TLC)}

Pre-coated Silica Gel Plates: TLC Silica gel 60 F254 Glass Plates $20 \times 20$ DC Kiesel gel (Merck 1.05715.0001) were used to separate tertiary alkaloids by preparative TLC. UV light $(254 / 366 \mathrm{~nm})$ was used for band detection. Chloroform:Methanol:Ammonia (95:5:0.05) were used as solvent system for $P$. glaucum where Benzene:Ethanol:Ammonia (9:1:0.01) were used for $P$. decaisnei. The bands were scraped and powdered. The alkaloids were then eluted with mixture of chloroform $\left(\mathrm{CHCl}_{3}\right)$ (Sigma Aldrich, Germany) and methanol (MeOH) (Sigma Aldrich, Germany) (9:1) and evaporated to dryness under nitrogen [7].

\section{${ }^{1} H$-NMR spectrum analysis}

The ${ }^{1} \mathrm{H}$ Nuclear Magnetic Resonance (NMR) spectra were recorded in deuterochloroform $\left(\mathrm{CDCl}_{3}\right)$ by VARIAN (Agilent) MERCURY $400 \mathrm{MHz}$ (Varian, Palo Alto, CA, USA) spectrometer with $400 \mathrm{MHz}$ proton resonance frequency in Ankara University Central Laboratory.

\section{UV spectrum analysis}

Shimadzu UV-2401/2501 spectrophotometer was used between 200 and 400 wavelength $/ \mathrm{nm}$. Spectra were made with methanol solution for $1 \mathrm{~cm}$ quartz cuvettes. Spectra were recorded by adding $50 \mu \mathrm{l}$ of $0.5 \mathrm{~N}$ sodium hydroxide $(\mathrm{NaOH})$ (Sigma Aldrich, Germany) solution to samples. $50 \mu \mathrm{l}$ of $0.5 \mathrm{~N} \mathrm{HCl}$ solution was added to sample solutions and the spectrum was recorded again [8].

\section{Minimum inhibitory concentration (MIC)}

For the MIC assessment, fresh bacterial broth cultures were prepared, standardized to $0.5 \mathrm{McFarland}$ and diluted with sterile PBS to $1 \times 10^{5} \mathrm{cfu} / \mathrm{ml}$. The extracts were serially diluted, bacterial culture was added to each tube and incubated at $37{ }^{\circ} \mathrm{C}$ for $18 \mathrm{~h}$. The absorbance was measured at $600 \mathrm{~nm}$ relative to the blank and the controls. The tests were done three times in triplicates [9].

\section{Results and discussion}

Extraction and separation of alkaloids from P. glaucum and $P$. decaisnei

The amount of plant material used and the yield of tertiary alkaloid extracts from P. glaucum (PG) and P. decaisnei (PD) aerial samples was $150 \mathrm{~g}$ and $100 \mathrm{~g}$ respectively. Extractions of PG and PD lead to $0.24 \%$ and $0.11 \%$ of extract yield respectively.

\section{Isolation and purification of P. glaucum and P. decaisnei alkaloids by preparative TLC}

Preparative TLC of PG tertiary extract allowed detection of three bands named PG1, PG2 and PG3 (Fig. 1a).

Preparative TLC of PD tertiary extract allowed detection of two prominent bands named PD1 and PD2 (Fig. 1b). The amount of extract obtained from PG and PD was calculated for each fraction (Additional file 2: Table S1).

Rf values obtained from TLC plates of PG and PD were calculated for PG1, PG2 and PG3 in Chloroform:Methanol:Ammonia (95:5:0.05) solvent system, where PD1 and PD2 were calculated in Benzene:Ethanol:Ammonia (9:1:0.01) solvent system (Additional file 3: Table S2).

\section{Identification of alkaloids from P. decaisnei and P. glaucum}

Structure elucidation of alkaloids were carried out based on UV spectroscopic analysis and ${ }^{1} \mathrm{H}-\mathrm{NMR}$ as well as TLC by direct comparison (except for palaudine) with authentic samples. ${ }^{1} \mathrm{H}$-NMR analysis of PD and PG fractions allowed determination of different alkaloids. Tertiary alkaloids isolated from PG 
a.

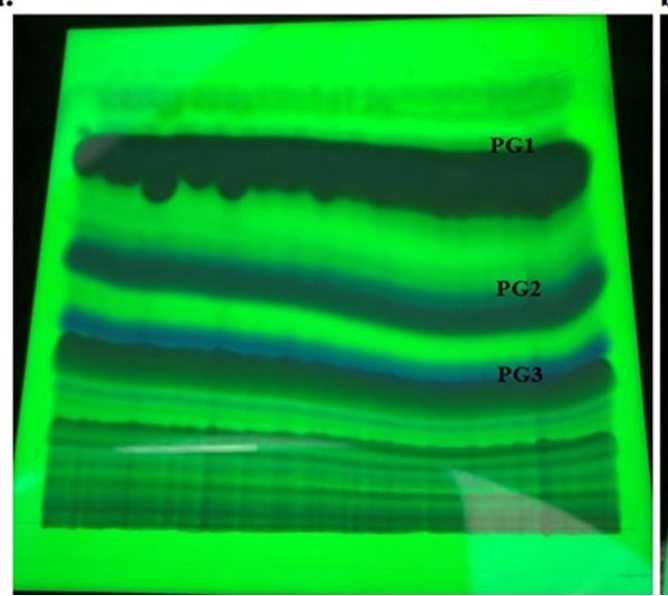

b.

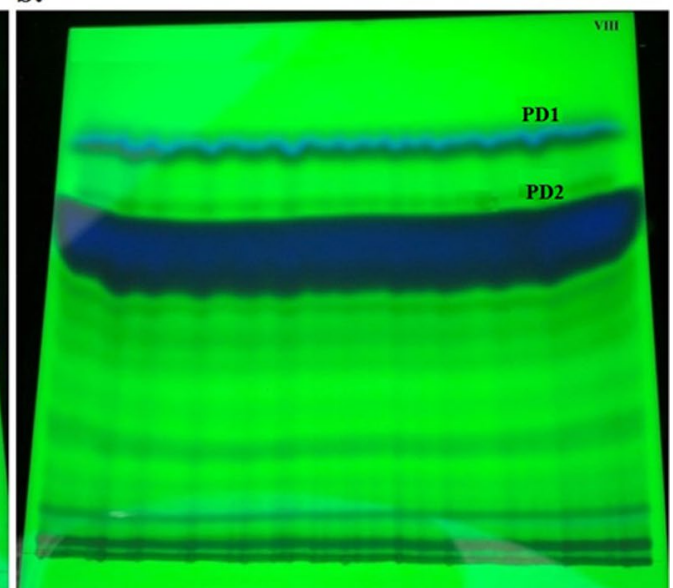

Fig. 1 Papaver glaucum (PG) (a) and P. decaisnei (PD) (b) alkaloids under UV Light 254/366 nm. TLC plate profile for fractionation of PG using Chloroform:Methanol:Ammonia (95:5:0.05) and PD using Benzene:Ethanol:Ammonia (9:1:0.01), showing specific bands of alkaloids. The three most prominent bands were termed PG1, PG2, PG3 for Papaver glaucum; PD1 and PD2 for P. decaisnei

were identified as benzylisoquinoline-types papaverine (PG1: $97 \mathrm{mg}$; Fig. 2a) and palaudine (PG2: $16 \mathrm{mg}$; Fig. 2b) as well as aporphine type $N$-methylasimilobine (PG3: $19 \mathrm{mg}$; Fig. 2c). Two alkaloids belonging to proaporphine-type (PD2: mecambrine, $43 \mathrm{mg}$; Fig. 2e) and aporphine-type alkaloids (PD1: roemerine, $6 \mathrm{mg}$; Fig. 2d) were obtained from PD.

While papaverine (PG1) was determined to be the major alkaloid, palaudine (PG2) was revealed as the minor alkaloid. The isolation of palaudine was first reported from $P$. somniferum [10] using HPLC and HPLC-MS studies, followed by PG [11]. Furthermore, the structure of palaudine as a minor alkaloid has been confirmed by ${ }^{1} \mathrm{H}-\mathrm{NMR}$ spectra and by comparing ${ }^{1} \mathrm{H}$ NMR ppm values with related data [11]. In line with previous studies [10, 11], our UV spectral data further confirm the similarity of palaudine and papaverine (Additional file 1: Fig. 1).

In our study, three signals at 3.75, 3.76 and $4.46 \mathrm{ppm}$ indicated the presence of three OMe at C6, C7 and C4. A methylene signal appears at $4.46 \mathrm{ppm}$. Presence of four doubles and 3 singlets corresponded to 6 aromatic protons. Methylene signals at 4.46 and at $4.52 \mathrm{ppm}$ in the ${ }^{1} \mathrm{H}$-NMR spectra of palaudine and papaverine respectively confirm their benzylisoquinoline structure (Fig. 2b and Fig. 2a). This is the first report of isolation of a benzylisoquinoline alkaloid papaverine as a major alkaloid in PG. The benzylisoquinoline papaverine and $N$-methylasimilobine have been shown for the first time in this species. However, isolation of $N$-methylasimilobine was not surprising since another aporphine alkaloid liriodenine, structurally similar to $N$-methylasimilobine, was previously shown in PG [3]. In addition to liriodenine, a previous investigation of Iraqi origin PG herbarium specimens reported the identification of roemerine, dehydroromerine, roemerine $\mathrm{N}$-oxide, rhoeagenine and glaucamine together with an unidentified aporpine [3].

The alkaloids of PD growing wild in Iraq were studied for the first time in our study. Isolation of total tertiary alkaloids from PD by preparative TLC, yielded two alkaloids, aporphine-type roemerine (PD1) as a minor alkaloid and proaporphine-type mecambrine (PD2) as major alkaloid. These alkaloids were isolated from PD for the first time. ${ }^{1} \mathrm{H}$-NMR spectra of mecambrine and roemerine (Fig. 2e and Fig. 2d) were compared with literature data and TLC Rf values were found to be identical with those of reference samples. Previous investigations of PD have revealed the presence of codeine, coptisine, corytuberine, isorhoeadine, morphine, narcotine, papaverine, papaverrubines, protopine, rhoeadine, roeagenine, thebaine, thebaine methohydroxide, and papaverine as the major alkaloid $[12,13]$.

\section{Antimicrobial activities of extracts from P. glaucum and $P$. decaisnei}

Various plant extracts and essential oils have been demonstrated to have antibacterial and antifungal activities, impacting even antimicrobial resistant species [14-16]. Multidrug resistant (MDR) bacteria are among the biggest challenges that global health care systems are faced with, as they not only resist classical therapy but they also have improved virulence mechanisms, including increased biofilm formation [17]. This issue requires thorough investigation of novel agents with 

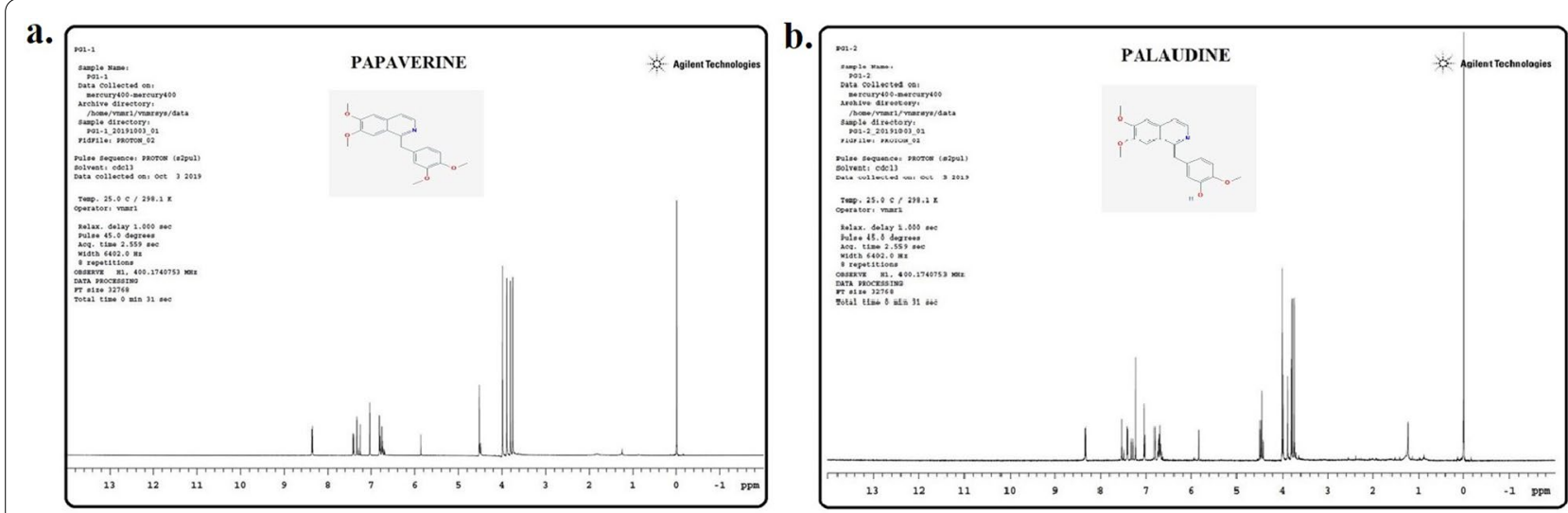

c.

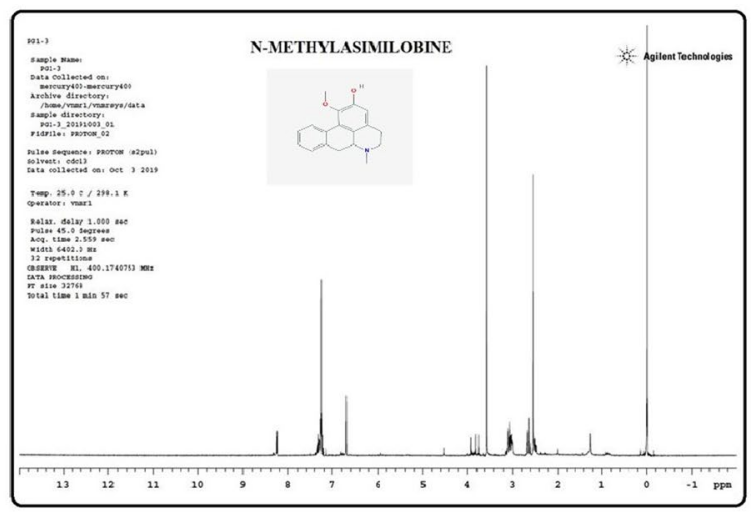

d.

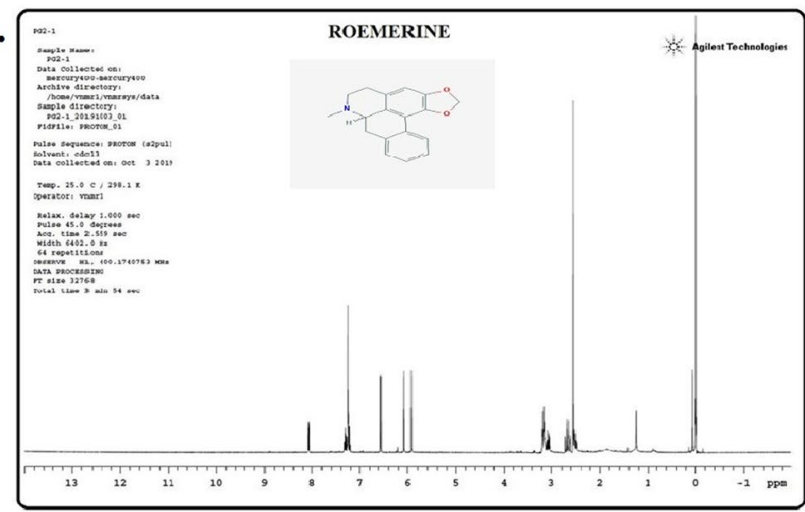

e.

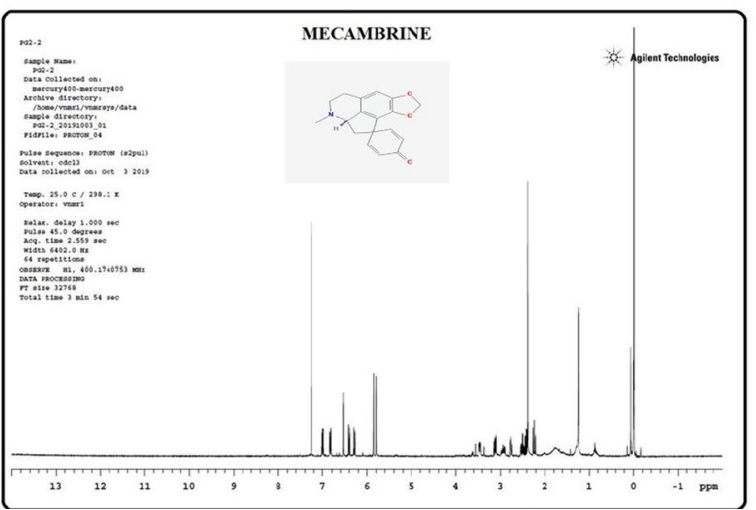

Fig. $2{ }^{1} \mathrm{H}$-NMR spectra of papaverine (a), palaudine (b), N-methylasimilobine (c) alkaloids obtained from Papaver glaucum and roemerine (d) and mecambrine (e) alkaloids obtained from $P$. decaisnei

antimicrobial and/or anti-virulence properties to provide candidates that can be translated as effective treatment approaches [18]. Alkaloids have historically been studied and utilized for their antimicrobial activities $[19,20]$. In our study, antibacterial activities of PG and PD alkaloids were investigated using minimum inhibitory concentration (MIC) assessment on both Gramnegative and Gram-positive bacteria. Methanol extracts and tertiary alkaloids obtained from PG and PD showed strong antimicrobial effect on Gram-positive Enterococcus faecalis ATCC 29212 and Gram-negative Pseudomonas aeruginosa ATCC 27853 (Table 1). While all tested methanol extracts exhibited antimicrobial effect, total tertiary alkaloids from both species demonstrated the most potent antimicrobial activity (Table 1). Particularly PDTA (P. decaisnei total tertiary alkaloids) exerted antimicrobial effect on both of the tested bacteria at $27.5 \mu \mathrm{g} / \mathrm{ml}$, the lowest concentration of all tested 
Table 1 Minimum inhibitory concentration ( $\mathrm{MIC}, \mu \mathrm{g} / \mathrm{ml}$ ) of methanol and total tertiary alkaloid extracts from PG and PD

\begin{tabular}{lll}
\hline PG and PD extracts & $\begin{array}{l}\text { Enterococcus faecalis } \\
\text { ATCC 29212 }\end{array}$ & $\begin{array}{l}\text { Pseudomonas } \\
\text { aeruginosa ATCC } \\
\mathbf{2 7 8 5 3}\end{array}$ \\
\hline PGME & $180 \mu \mathrm{g} / \mathrm{ml}$ & $90 \mu \mathrm{g} / \mathrm{ml}$ \\
PDME & $200 \mu \mathrm{g} / \mathrm{ml}$ & $200 \mu \mathrm{g} / \mathrm{ml}$ \\
PGTA & $47 \mu \mathrm{g} / \mathrm{ml}$ & $47 \mu \mathrm{g} / \mathrm{ml}$ \\
PDTA & $27.5 \mu \mathrm{g} / \mathrm{ml}$ & $27.5 \mu \mathrm{g} / \mathrm{ml}$ \\
Ampicillin & $3.12 \mu \mathrm{g} / \mathrm{ml}$ & $1.56 \mu \mathrm{g} / \mathrm{ml}$ \\
\hline
\end{tabular}

PGME: P. glaucum ethanol extract; PDME: $P$. decaisnei methanol extract; PGTA: $P$. glaucum total tertiary alkaloids; PDTA: P. decaisnei total tertiary alkaloids

alkaloids. P. glaucum tertiary alkaloids (PGTA) demonstrated antimicrobial activity on both tested microorganisms starting at $47 \mu \mathrm{g} / \mathrm{ml}$ (Table 1). Methanolic extracts from both PG and PD exhibited antimicrobial effect, however with reduced potency, when compared with isolated total tertiary alkaloids (Table 1). The MIC values for methanol extracts were 2-four fold higher for PG and about seven fold higher for PD when compared with their total tertiary alkaloids, highlighting total tertiary alkaloids' effectivity (Table 1$)$. PGME $(P$. glaucum methanol extracts) exhibited a fold increase in antimicrobial activity towards the Gram-negative $P$. aeruginosa $(90 \mu \mathrm{g} / \mathrm{ml})$ compared to the Gram-positive E. faecalis $(180 \mu \mathrm{g} / \mathrm{ml})$. Collectively, our results reveal the strong antimicrobial activity of PG and PD extracts, especially highlighting the antibacterial effectivity of their total tertiary alkaloids.

In addition to their antibacterial activity [21], alkaloids have antibiotic enhancing and antivirulence activities where they served as scaffolds for important antibacterial drugs like metronidazole and quinolones [22]. Alkaloids mostly exhibit antibacterial activity through depolarizing the cell wall, intercalating into bacterial DNA and inhibiting mRNA transcription [23, 24]. Anti-virulence properties associated with alkaloids include preventing biofilm formation via interfering with regulation of virulence genes as well as impacting quorum sensing and expression or function of sortases, adhesins and various secretion systems [25].

While mecambrine and roemerine may synergistically be contributing to the antimicrobial activity observed with PD alkaloids, strong antimicrobial effect is likely roemerine mediated. Tsai and co-workers have previously shown antimicrobial effects of roemerine on Bacillus cereus, Micrococcus sp, and Staphylococcus aureus [26]. Roemerine was previously reported to alter S. aureus membrane permeability [27].

$N$-methylasimilobine alkaloid whose phenolic character was confirmed by UV spectra taken in $0.5 \mathrm{~N} \mathrm{NaOH}$
(Additional file 1: Fig. S1) [28], was thought to contribute towards antimicrobial activity against Grampositive bacteria [29] in addition to having moderate antioxidant capacity [30].

\section{Conclusion}

Overall, our study provides a thorough investigation of the alkaloid contents of two understudied species, $P$. glaucum and $P$. decaisnei. We report, for the first time, the isolation of roemerine and mecambrine from $P$. decaisne $i$ and isolation of papaverine and $N$-methlyasimilobine from $P$. glaucum while further establishing benzylisoquinoline alkaloid papaverine as a major alkaloid in P. glaucum. These Papaver species and their extracts were also studied for the first time for their antimicrobial properties where their antimicrobial activities against pathogenic microorganisms, E. faecalis and $P$. aeruginosa were elucidated. We reveal the potential of these plant species to further be utilized in antimicrobial, antivirulence or synergistic, antibiotic-enhancing studies.

\section{Limitations of the study}

Papaver glaucum and $P$. decaisnei samples were collected from wild in Northern Iraq and their alkaloid content were studied in Cyprus. Limited amount of sample allowed investigation of their alkaloid content on limited number of pathogens.

\section{Abbreviations \\ ${ }^{1} \mathrm{H}$-NMR: Hydrogen' Proton nuclear magnetic resonance; ABTS: 2, 2'-Azino-bis (3-ethylbenzothiazoline-6-sulfonic) acid; ATCC: American Type Culture Collec- tion; BALB/c: Albino laboratory-bred strain house mouse; cfu/ml: Colony form- ing unit per millilitre; $\mathrm{CIUH}$ : Cyprus International University Herbarium; $\mathrm{CHCl}_{3}$ : Chloroform; DNA: Deoxyribonucleic acid; DPPH: 2,2-Diphenyl-1 picrylhydrazyl; HCl: Hydrochloric acid; HPLC: High Performance Liquid Chromatography; HPLC-MS: High Performance Liquid Chromatography-Mass Spectrometry; MeOH: Methanol; MHz: Mega Hertz; MIC: Minimum inhibitory concentration; mRNA: Messenger ribonucleic acid; $\mathrm{NaOH}$ : Sodium hydroxide; $\mathrm{NaSO}$ : Sodium sulphate; $\mathrm{NH}_{3}$ : Ammonia; OMe: Methoxy group; PD: P. decaisnei; PG: P. glaucum; PDME: P. decaisnei methanol extracts; PDTA: P. decaisnei total tertiary alkaloids; PGME: P. glaucum methanol extracts; PGTA: P. glaucum tertiary alkaloids; Ppm: Parts per million; Rf: Retention factor; SV: Solvent-system; TLC: Thin-layer chro- matography; UV: Ultraviolet.}

\section{Supplementary Information}

The online version contains supplementary material available at https://doi. org/10.1186/s13104-021-05762-x.

Additional file 1: Figure S1. UV visible spectra of Papaver glaucum and $P$. decaisnei alkaloids

Additional file 2: Table S1. Isolated alkaloids from PG and PD extract.

Additional file 3: Table S2. Rf Values of Alkaloids Obtained from P. glaucum (PG) and P. decaisnei (PD) Extracts. 


\section{Acknowledgements}

Authors would like to extend their acknowledgements to Prof. Dr. Neriman Ozhatay and Prof. Dr. Mehmet Koyuncu for identification of plant samples and Prof. Dr. Hakan Göker from Ankara University, Faculty of Pharmacy for ${ }^{1}$ HNMR spectra analysis.

\section{Authors' contributions}

HJJ collected plant samples, conducted the experiments wrote the paper. OI designed the antimicrobial activity experiments and wrote the paper. EV coordinated antimicrobial activity experiments and wrote the paper. GS designed the study, coordinated the experiments, and wrote the paper. All authors read and approved the final manuscript.

\section{Funding}

This research was funded by Cyprus International University Faculty of Pharmacy.

\section{Availability of data and materials}

The datasets supporting the conclusions of this article are available upon request and samples are available in the repository of Cyprus International University herbarium.

\section{Declarations}

\section{Ethics approval and consent to participate}

Not applicable.

\section{Consent to publish}

Not applicable.

\section{Competing interests}

The authors declare that they have no competing interests.

\section{Author details}

${ }^{1}$ Faculty of Pharmacy, Cyprus International University, via Mersin 10, 99258 Nicosia, Northern Cyprus, Turkey. ${ }^{2}$ Biotechnology Research Center, Cyprus International University, via Mersin 10, 99258 Nicosia, Northern Cyprus, Turkey.

Received: 8 July 2021 Accepted: 26 August 2021

Published online: 08 September 2021

\section{References}

1. Shetge SA, Dzakovich MP, Cooperstone JL, Kleinmeier D, Redan BW. Concentrations of the opium alkaloids morphine, codeine, and thebaine in poppy seeds are reduced after thermal and washing treatments but are not affected when incorporated in a model baked product. J Agric Food Chem. 2020;68(18):5241-8. https://doi.org/10.1021/acs.jafc.0c01681 (Epub 2020 Apr 27).

2. Sariyar G. Biodiversity in the alkaloids of Turkish Papaver species. Pure Appl Chem. 2002;74(4):557-74. https://doi.org/10.1351/pac2002740 40557.

3. Phillipson JD, Gray Al, Askari AAR, Khalil AA. Alkaloids from Iraqi species of Papaveraceae. J Nat Prod. 1981;44:296.

4. Hussain G, Rasul A, Anwar H, Aziz N, Razzaq A, Wei W, Ali M, Li J, Li X. Role of plant derived alkaloids and their mechanism in neurodegenerative disorders. Int J Biol Sci. 2018;14(3):341-57. https://doi.org/10.7150/ijbs. 23247.

5. Chaves SK, Feitosa CM, da Araújo SL. Alkaloids pharmacological activities - prospects for the development of phytopharmaceuticals for neurodegenerative diseases. Curr Pharm Biotechnol. 2016;17(7):629-35. https:// doi.org/10.2174/138920101707160503201541.

6. Cullen J, Townsend CC, Guest E. Flora of Iraq. Minist Agric Agrar Reform Repub Iraq. 1980;4:2.

7. Çoban I, Toplan GG, Özbek B, Gürer ÇU, Sarıyar G. Variation of alkaloid contents and antimicrobial activities of Papaver rhoeas L. growing in Turkey and northern Cyprus. Pharm Biol. 2017;55(1):1894-8. https://doi. org/10.1080/13880209.2017.1340964.
8. Kalav YN, Sariyar G. Alkaloids from Turkish Papaver rhoeas. Planta Med. 1989;55(5):488. https://doi.org/10.1055/s-2006-962072.

9. Kowalska-Krochmal B, Dudek-Wicher R. The minimum inhibitory concentration of antibiotics: methods, interpretation, clinical relevance. Pathogens. 2021;10(2):165. https://doi.org/10.3390/pathogens10020165.

10. Brochmann-Hanssen E, Hirai K. Opium alkaloids. Biosynthesis of benzylisoquinolines. J Pharm Sci. 1968;60:1672-6.

11. Brochmann-Hanssen E, Hirai K. Opium alkaloids VII. Isolation of a new benzylisoquinoline alkaloid. Synthesis and NMR studies of papaveroline trimethyl ethers. J of Pharm Sci. 1968;57(6):940-3.

12. Ziegler J, Diaz-Chavez ML, Kramell R, Ammer C, Kutchan TM. Comparative macroarray analysis of morphine containing Papaver somniferum and eight morphine free Papaver species identifies an O-methyltransferase involved in benzylisoquinoline biosynthesis. Planta. 2005;222:458-71.

13. Slavik J. Occurrence of morphine as minor alkaloid in P. decaisnui Hochst. Collect Czech Chem Commun. 1980;45:2706-9.

14. Donadu MG, Peralta-Ruiz Y, Usai D, Maggio F, Molina-Hernandez JB, Rizzo D, Bussu F, Rubino S, Zanetti S, Paparella A, Chaves-Lopez C. Colombian essential oil of Ruta graveolens against nosocomial antifungal resistant Candida strains. J Fungi. 2021;7(5):383. https://doi.org/10.3390/jof70 50383.

15. Mazzarello V, Gavini E, Rassu G, Donadu MG, Usai D, Piu G, Pomponi V, Sucato F, Zanetti S, Montesu MA. Clinical assessment of new topical cream containing two essential oils combined with tretinoin in the treatment of acne. Clin Cosmet Investig Dermatol. 2020;13:233-9. https://doi. org/10.2147/CCID.S236956.

16. Cannas S, Usai D, Pinna A, Benvenuti S, Tardugno R, Donadu M, Zanetti S, Kaliamurthy J, Molicotti P. Essential oils in ocular pathology: an experimental study. J Infect Dev Ctries. 2015;9(6):650-4. https://doi.org/10. 3855/jidc.6842.

17. Senobar Tahaei SA, Stájer A, Barrak I, Ostorházi E, Szabó D, Gajdács M. correlation between biofilm-formation and the antibiotic resistant phenotype in Staphylococcus aureus isolates: a laboratory-based study in Hungary and a review of the literature. Infect Drug Resist. 2021;23(14):1155-68. https://doi.org/10.2147/IDR.S303992.

18. Gajdács M. The concept of an ideal antibiotic: implications for drug design. Molecules. 2019;24(5):892. https://doi.org/10.3390/molecules2 4050892 (Published 2019 Mar 3).

19. Doncheva T, Kostova N, Valcheva V, Toshkovska R, Vutov V, Philipov S. Hypepontine, a new quaternary alkaloid with antimicrobial properties. Nat Prod Res. 2020;34(5):668-74. https://doi.org/10.1080/14786419.2018. 1495640.

20. Davies MK, Hollman A. The opium poppy morphine, and verapamil. Heart. 2002;88(1):3

21. Othman L, Sleiman A, Abdel-Massih RM. Antimicrobial activity of polyphenols and alkaloids in middle eastern plants. Front Microbiol. 2019;10:911. https://doi.org/10.3389/fmicb.2019.00911 (Published 2019 May 15).

22. Cushnie TP, Cushnie B, Lamb AJ. Alkaloids: an overview of their antibacterial, antibiotic-enhancing and antivirulence activities. Int J Antimicrob Agents. 2014;44(5):377-86. https://doi.org/10.1016/j.ijantimicag.2014.06. 001 (Epub 2014 Jul 15).

23. Raji P, Samrot AV, Keerthana D, et al. Antibacterial activity of alkaloids, flavonoids, saponins and tannins mediated green synthesised silver nanoparticles against Pseudomonas aeruginosa and Bacillus subtilis. J Clust Sci. 2019;30:881-95. https://doi.org/10.1007/s10876-019-01547-2.

24. Gaber A, Alsanie WF, Kumar DN, Refat MS, Saied EM. Novel papaverine metal complexes with potential anticancer activities. Molecules. 2020;25:5447. https://doi.org/10.3390/molecules25225447.

25. Kim SH, Shin DS, Oh MN, Chung SC, Lee JS, Oh KB. Inhibition of the bacterial surface protein anchoring transpeptidase sortase by isoquinoline alkaloids. Biosci Biotechnol Biochem. 2004;68(2):421-4. https://doi.org/10. 1271/bbb.68.421.

26. Tsai IL, Liou YF, Lu ST. Screening of isoquinoline alkaloids and their derivatives for antibacterial and antifungal activities. Kaohsiung J Med Sci. 1989:5:132-45.

27. Yin S, Rao G, Wang J, Luo L, He G, Wang C. Roemerine improves the survival rate of septicemic BALB/C mice by increasing the cell membrane permeability of Staphylococcus aureus. PLOS ONE. 2015;10(11):e0143863. 
28. Kunitomo JI, Yamamoto C, Otsuki T. The alkaloids of Nelumbo nucifera Geartn. VI. Alkaloids of "Gen-shi-hasu."J Pharm Soc Jap. 1964;1964(84):1141.

29. Shukla S, Park J, Park JH, Lee JS, Kim M. Development of novel Meju starter culture using plant extracts with reduced Bacillus cereus counts and enhanced functional properties. Sci Rep. 2017;7(1):11409. https://doi. org/10.1038/s41598-017-09551-0 (Published 2017 Sep 12).

30. Liu CM, Kao CL, Wu HM, Li WJ, Huang CT, Li HT, Chen CY. Antioxidant and anticancer aporphine alkaloids from the leaves of Nelumbo nucifera
Gaertn. Cv. Rosa-plena. Molecules. 2014;19:17829-38. https://doi.org/10. 3390/molecules191117829.

\section{Publisher's Note}

Springer Nature remains neutral with regard to jurisdictional claims in published maps and institutional affiliations.
Ready to submit your research? Choose BMC and benefit from:

- fast, convenient online submission

- thorough peer review by experienced researchers in your field

- rapid publication on acceptance

- support for research data, including large and complex data types

- gold Open Access which fosters wider collaboration and increased citations

- maximum visibility for your research: over $100 \mathrm{M}$ website views per year

At BMC, research is always in progress.

Learn more biomedcentral.com/submissions 